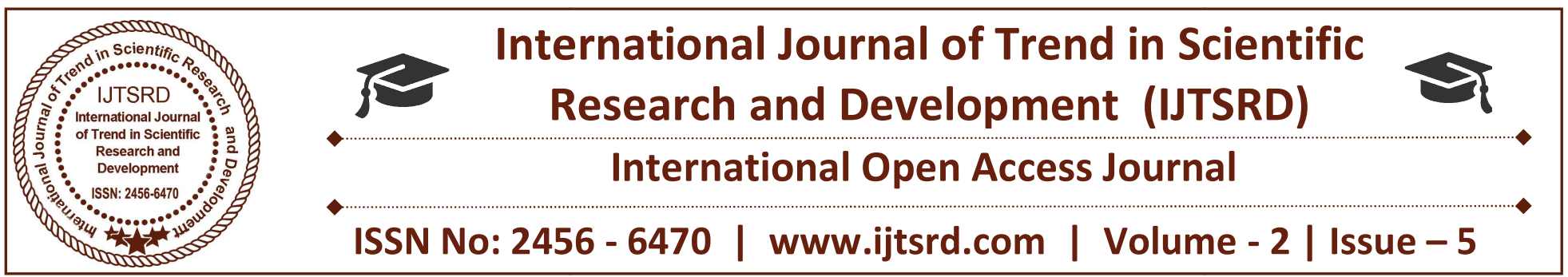

\title{
Effects in Day to Day Life Due to the Changing Concept of Caveat Emptor
}

\author{
Divya Soni \\ B.A., LL.B (Hons), Indore Institute of Law \\ Indore, Madhya Pradesh, India
}

\begin{abstract}
:
"Let the buyer beware" was the slogan about three decades ago which has been changed to "Let the seller beware" with the induction of the Consumer Protection Act, 1986 in the Indian Legal System. This has paved a new jurisprudence of the consumer laws in India where the consumer enjoys every comfort of goods or services. The Act has enshrined to the consumer certain basic enforceable rights and the three level redressal mechanisms, the District Forum, State Commission and the National Commission to strengthen the rights.
\end{abstract}

\section{INTRODUCTION}

The Consumer product safety laws have originated and developed as a natural response to the recognition of the rights of every consumer to be protected against exploitation and abuse by any manufacturer or supplier of goods or service providers. The idea of consumer protection can be found to have existed in every kind of social order and judicial mechanism, whether primitive or modern. However, the extent to which it has been emphasized and seeks to be flourished has varied depending upon the variations in circumstances. This reality draws support not only from customary norms of buying and seeking services but also from many religious ordainments and commands of kings. The protection of consumers has, therefore, been a continuous process with different dimensions, more often than not, slow and compromising. The major developments on maintenance of product safety standards are occurred in the U.K. and U.S.

\section{Aim and objective:}

The purpose of this study is that in the days when buying and selling was carried on in the local marketplace, the rule was a practical one. Buyer and seller knew each other and were on equal footing. The nature of modern commerce and technology placed the buyer at a disadvantage, however, so a stack of regulations have been written by federal, state, and local agencies to protect the consumer against dangerous or defective products, fraudulent practices, and the like. But the principle that a buyer needs a warranty if he is to avoid risk remains an important legal concept.

\section{Research Methodology:}

During this paper the researcher will follow doctrinal research method as doctrinal research asks what the law is on a particular issue. This type of research is also known as pure. Also content analysis of available secondary data.

\section{Research Question:}

1. What is caveat emptor? How it changed to caveat venditor?

2. What are the rights of a vendor? What are Consumer Disputes Redressal Agencies?

\section{Historical development}

\section{Early history of caveat emptor}

The attitude of common law in the 19th century towards the buyer may be summed up by the maxim caveat-emptor (let the buyer beware). This maxim summarizes the rule that a purchaser must examine and judge what is best for him. The purchaser takes risk of quality and condition unless he protects himself by a warranty or there has been false 
representation. It applies, with certain specific restrictions, not only to the quality but also the title of the thing, which is sold. The maxim caveat emptor is based upon the presumption that the buyer is relying on his own skill and judgment, when he makes a purchase. ${ }^{1}$ It means that subject to the implied conditions and the exceptions created thereby, the seller is not bound to supply goods which should be fit for any particular purpose or which should possess any particular quality. It is buyers' duty to select the goods of his requirement. The buyer, therefore, had every opportunity to satisfy himself as to the quality of the goods or their fitness for a particular purpose, and at common law it was presumed that where the buyer could examine the goods even though he did not do so, he relied upon his own skill and judgment.

\section{How it changed to caveat venditor}

The caveat emptor principle, that literally means let the buyer beware, has been followed for many years by the Courts of England. These simple words were an easy focus for judicial thought, a principle to be invoked when the going is difficult, a guide to be followed amid the baffling uncertainties of litigation. Emptor in Latin is the buyer and the verb cavere is a verb of caution: caveat emptor was the perfect principle for transactions involving not massive quantity of goods. ${ }^{2}$

A lot of cases in medieval times were decided by the rules of the lex mercatoria in special courts, but for other than the basic rights such as the right of the seller to payment and the right of the buyer to the goods, private law was not very interested. As a matter of fact the criminal law and statutes that prohibited the use of false measures and the adulteration of food, beer and wine, regulated the major part of claims about the sale of goods and there were local policies regulating the trade fairs that changed from place to place. ${ }^{3}$

The principle of caveat emptor was the guideline for the courts and the point was that the buyer had the chance to use his knowledge to be careful or accept the cost of his inattention. No warranties were implied to assure the quality of the goods he was going to buy and only a seller making a false statement could be

\footnotetext{
${ }^{1}$ caveat\%20emptor/ last visited on 21 July at $10 \mathrm{pm}$

https://chicagounbound.uchicago.edu/cgi/viewcontent.cgi?artic le $=3669 \&$ context=uclrev last visited on 21 july at $11 \mathrm{pm}$

sued in tort for deceit. In such a case he was not simply assuming a fact but giving a clear warranty to the buyer he could be sued even though he did not know about the falseness of his affirmation. ${ }^{4}$

In the case of false affirmation of the seller there was no need of a written warranty; it was sufficient that the buyer was convinced to buy by the false statements of the seller to imply this particular warranty and, even though a contract was necessary, there was no need that the guarantee was a part of the contract. However it is very important to point out that all this concerned fraud and that was the only way for the buyer to sue the seller for breach of the contract: no implied terms arose if the seller did not make any false statement. As we have said this situation was perfect if you try to imagine the scenario of the sales in medieval times: there were small fairs and small quantities of limited types of goods to be sold. The buyer often had the knowledge to recognize defective goods and to discuss the price with the seller who, instead of offering a written warranty, could accept an eventual reduction in price.

The case that clearly illustrates the situation up to seventeenth century is Chandelor v. Lopus in which the plaintiff brought an action against the defendant for the selling of a Bezoar Stone. This particular stone, found in the stomach of some animals, was supposed to have medicinal properties. The majority of the court held that the evidence was insufficient to find the defendant liable because of the absence of any written warranty. ${ }^{5}$

As already noted, the action for the breach of contractual rights did need, at the time, a written warranty and, in absence of the latter, the only possibility was an action for fraud. ${ }^{6}$

\section{Fundamental concepts \\ Three-Tier Radical System}

The Consumer Protection Act, 1986 has granted certain rights for the protection of consumers ${ }^{\text {ee }}$ interests. This heavy burden has been allotted to the Consumer Dispute Redressal Agencies formed through the Act [9]. These agencies have been further categorized under three different tiers:

\footnotetext{
${ }^{4}$ Venditor - a Brief History of English Sale of Goods Law Litigation, Mediation \& Arbitration - Italy.html last visited on 22 July at $7 \mathrm{pm}$

${ }^{5}$ ibid

${ }^{6}$ caveat\%20venditor lat visited on 22 July at 11 pm
} 
1. Consumer Dispute Redressal Forum, i.e., District Forum.

2. Consumer Dispute Redressal Commission, i.e., State Commission.

3. National Consumer Dispute Redressal Commission.

\section{Legal framework}

Monopolies, Restrictive and Unfair Trade Practices

The Monopolies and Restrictive Practices (Inquiry and Control) Act of 1948, was the first law enacted by the British Parliament for regulation and control of monopolies in the United Kingdom. A monopoly and restrictive trade practices commission was set up which was renamed as Monopolies Commission in 1956, when authority over restrictive trade practices was transferred to the restrictive practices Court set up under the Restrictive Trade Practices Act of the that year. Another law the Monopolies and Mergers Act, 1965 vested the Commission with power to investigate mergers.

Restrictive Trade Practices Act, 1956 brought into existence the Restrictive Practices Court, and under this law certain agreements, which restricted competition, were required to be registered with the Registrar of Restrictive Trading Agreements. The legislative provisions have now been consolidated in the Restrictive Trade Practices Act, 1976 as amended from time to time. ${ }^{7}$

\section{Consumer Credit and Exploitation}

With the availability of credit facilities, it has been possible for a consumer to change the living style by acquiring consumer goods such as T.V., Stereo, Car, Scooter, Refrigerator and the like. The unscrupulous traders have exploited the consumers in several ways and it was evident that state regulation would be necessary to protect them from manifestly unfair transactions. The Hire Purchase Act, 1938 sought to remedy such anomalous situations and provides relief to the affected consumer. The Hire-Purchase Act, 1965 , then replaced it. ${ }^{8}$

\section{Unfair Trade}

With regard to tortious liability it may be noted that until recently it was possible for a person to exclude liability for negligence and this device was used

\footnotetext{
${ }^{7}$ ibid

${ }^{8}$ https://fee.org/articles/caveat-emptor-the-consumers-badgeof-authority/ last visited on 21 July at 11:15 pm
}

extensively in contracts for supply of goods or services. The Unfair Trade terms Act 1977, contains provisions to suppress this evil. It is laid down that as exemption clause, which excludes or limits liability for negligence causing physical injury or dealt would be unenforceable. With respect to damage or loss of property caused by negligence such exemption clause may be upheld if it is reasonable. ${ }^{9}$

\section{Unfair Trade Description}

Cases of false or misleading trade descriptions advertisements are covered under the Trade Description Act, 1968, which makes it an offence for a person in the course of business or trade to apply false trade description to any goods. No mens rea is required in the cases of false description of goods the liability there being absolute. There are several defences available such as that the accused did not know and could not with reasonable diligence have known that the description was false or it was done under a mistake or it was due to some other person over whom he had no control. In all such cases, however, it is necessary to show that he took all reasonable precautions to avoid commission of the offence. Later the Trade Description Act has replaced the Merchandise Mark Act, $1987 .^{10}$

\section{Other Safety Legislations}

The safety legislations re-enacted on numerous separate specific products, e.g. food, drugs (Food and Drug Act 1955), weights, measures (Weight and Measures Act 1985), motor vehicles, electrical appliances, and for specific places or activities, e.g., factories, mines, sports grounds. The problem continually arose for the replaced and extended by the Consumer Safety Act, 1978, Consumer Protection Act, 1987, British Standards Institution Act, Food Safety Act, 1990, General Product Safety Regulations, 1994 and these regulations were replaced by General Product Safety Regulations, 2005. These Acts and Regulations provide that 'consumer goods' must comply with the 'the general safety requirement'. ${ }^{11}$

\section{Judicial trends}

In Ward v. Hobbes (1878) 4 AC 13, the House of Lords held that a vendor cannot be expected to use artifice or disguise to conceal the defects in the

\footnotetext{
${ }^{9}$ Supra1

${ }^{10}$ caveat\%20emptor.legal\%20freamework last visited on 22 July at $11: 45 \mathrm{pm}$

${ }^{11}$ Supra2
} 
product sold, since that would amount to fraud on the vendee; yet the doctrine of caveat emptor does not impose duty on vendor to disclose each and every defect in the product. The caveat emptor imposes such obligation on vendee to use care and skill while purchasing such product.

In Wallis v. Russel (1902) 2 IR 585, the Court of Appeal explained the scope of caveat emptor- "Caveat emptor does not mean in law that the buyer must "take a chance," it means he must "take care." It applies to the purchase of specific things, e.g. a horse, or a picture, upon which the buyer can, and usually does, exercise his own judgment; it applies also whenever the buyer voluntarily chooses what he buys; it applies also whereby usage or otherwise it is a term of the contract, that the buyer shall not rely on the skill or judgment of the seller.,"12

\section{Exceptions to the Rule of Caveat Emptor- Section 16 of the Sale of Goods Act, 1930 \\ Section 16(1) - Fitness for buyer's purpose}

Sub section (1) of Section 16 of the said Act prescribes the circumstances in which the seller is obliged to supply goods to the buyer as per the purpose for which he intends to make a purchase. It states that when the seller either expressly or by necessary implication is aware of the purpose for which buyer makes purchase thereby relying on seller's skill and judgment and the goods to be purchased are of a description which the seller in his ordinary course of business supply, then there is as implied condition that the goods shall be reasonably in accordance with the purpose

\section{Requirements of the Section 16(1) are as follows:-}

$>$ The buyer should make the seller aware of the particular purpose for which he is making purchase;

$>$ The buyer should make purchase on the basis of seller's skill or judgment;

$>$ The goods must be of a description which it is in the course of the seller's business to supply.

In the case of Shital Kumar Saini v. Satvir Singh, the petitioner purchased a compressor with one year warranty. The defect appeared within three months. The petitioner asked for a replacement. The seller replaced it but without providing any further

\footnotetext{
${ }^{12}$ https://blog.ipleaders.in/exceptions-rule-caveat-emptor/ last visited on 22july at 11:50 pm
}

warranty. The State Commission allowed it to be rejected stating that there was an implied warranty guaranteed under Section 16 of the Sale of Goods Act, 1930 that the goods should be reasonably fit for the purpose for which they are sold. ${ }^{13}$

\section{Sale under Trade Name}

Sometimes a buyer purchases goods not on the basis of skill and judgment of the seller but by relying on the trade name of the product. In such case, it would be unfair to burden the seller with the responsibility for quality. The proviso to Section 16 of the Sale of Goods Act, 1930 deals with such cases. The proviso says:

"Provided that, in the case of a contract for the sale of a specified article under its patent or other trade name, there is no implied condition as to the fitness for any particular purpose."

\section{Merchantable quality [Section 16(2)]}

The second important exception to the doctrine of caveat emptor is incorporated in Section 16(2) of the Act. The Section provides that the dealer who sells the goods has a duty to deliver the goods of merchantable quality.

Sub-Section (2) which contains this exception says: "Where the goods are bought by description from a seller who deals in goods of that description (whether he is the manufacturer or producer or not), there is an implied condition that the goods shall be of the merchantable quality."

Meaning of Merchantable Quality: Merchantable quality means that if the goods are purchased for resale they must be capable of passing in the market under the name or description by which they are sold. Merchantable quality depends on two factors:-

Marketability-Merchantability does not merely mean that the goods shall be marketable, but that they shall be marketable at their full value. "Merchantability does not mean that the things are saleable in the market because it looks all right; it is not merchantable in that event if it has defects unfitting it for its only proper use but not apparent on ordinary examination."

Reasonable fitness for general purposes"Merchantable quality" means, in the second place,

13 ibid 
that if the goods are purchased for self-use, they must be reasonably fit for the purpose for which they are generally used. Example: The plaintiff bought a hotwater bottle which is ordinarily used for application of heat to the human The bottle burst scalding the plaintiff's wife. The seller was held liable.

\section{Conclusion}

Before concluding the paper, I would like to put forward certain suggestions:

Consumer Education: Campaigns, seminars, street plays, distribution of pamphlets, etc. concerning consumer rights must be arranged frequently. Organizations of programs must necessarily be done on panchayat or tehsil levels as most of the unaware and uneducated class of consumers reside there and the events should serve the purpose to make them literate about their rights.

Mediation: The Consumer Law must provide an option of mediation before the parties as a method of arbitration to solve their disputes, hence reducing time consumption.

Strengthen Helpline Facilities: As we have earlier discussed, the Consumer help lines are mostly noneffective; the government needs to take a glance upon the issue and come up with a scheme to overhaul the inefficient help-tech.

Minimum amount payable: Section 14(1) (b) of the Consumer Protection Act, 1986 provides that the minimum amount of sum payable as damage shall not be less than $5 \%$ of value of defective goods. The authors propose to increase this minimum amount. The government should be petitioned to take steps to this effect as soon as possible.

Punitive damages in misleading advertisements: In cases of damage being caused to mass population, harsher punishment should be awarded to the party at fault.

Investigation and Inspection Teams: Investigation and inspection teams must be formed and in case of any complaint regarding irregularities of sellers, merchandisers, etc., they should be called upon.

Social Responsibility: Unless and until the society itself determines to be protected, no Act can do some good. One educated must make aware another of his rights. Besides, major consumer groups and NGOs have been established in big cities and the same should be followed in the other parts of the country.

Consumers have always been known as the vulnerable side of the society. Nevertheless, the Consumer Protection Act, 1986 has taken a dive to bestow justice upon the ones who suffer without guilt. In a way, it has personified its motto, "Justice Prevails". On the contrary, Milton Friedman had once justified himself by quoting, "Many people want the government to protect the consumer. A much more urgent problem is to protect the consumer from the government." Looks that, implementation of laws has modeled the same theory in India. A picture paints a thousand words. Likewise, the functioning of consumer laws can be deduced only by having a scrutiny of the various forums across the country. Each forum would accommodate diverse people with diverse dilemmas. What's more spontaneous to infer is that India is a country where laws are overflowing. The call of the hour is to modify and revamp these laws so that peace and tranquility sustains. On the whole, consumer protection laws are gold in themselves but to uphold its real shine, the law makers need to polish them every now and then.

\section{Bibliography}

1. http://www.drishtiias.com

2. http://www.mondaq.com

3. https://www.quora.com

4. http://www.legalserviceindia.com

5. http://www.yourdictionary.com

6. http://www.sac-be.com

7. http://www.academia.edu 